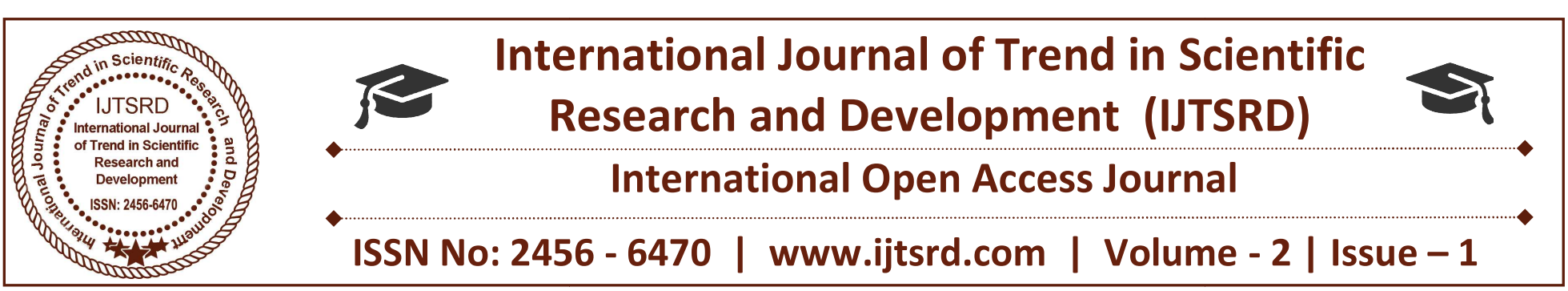

\title{
Preliminary Phytochemical Testing and Antimicrobial activity of Calotropis procera leaves.
}

\author{
Sagar Bashyal, Shubham Rai, Osama Abdul Manan, Faiz Hashmi, Avijit Guha \\ Department of Biotechnology, College of Engineering and Technology, \\ IILM-AHL, Greater Noida, Uttar Pradesh, India
}

\begin{abstract}
Naturally found plants have become the boon to the field of herbal science and medicine. For the detection of bioactive principles present in the medicinally important plants, a preliminary screening of the phytochemicals is the valuable step which may lead to drug discovery and development. In this study, chief phytoconstituents from the leaves and roots of Calotropis procera were identified and further antimicrobial activity was studied. Screening of Calotropis procera was performed for the presence of alkaloids, carbohydrates, saponins, phenols, flavonoids, tannins, anthocyanins, proteins and terpenoids using standard methods. It was found that all the three extracts showed the presence of carbohydrates and saponins. Alkaloids, proteins and tannins presence was seen in methanol and acetone extracts. Further, flavonoids presence was seen in the methanol and aqueous extracts. The aqueous, methanolic, acetone solvents extract was prepared to test antimicrobial activity taking $E$. coli. The prepared extracts were subjected to antimicrobial activity against $E$. coli using agar well diffusion method where Polymyxin-B for E. coli was taken as a control. Methanol, acetone and aqueous extract showed a zone of inhibition of $9.5 \mathrm{~mm}$, $4 \mathrm{~mm}$ and $6 \mathrm{~mm}$ respectively.
\end{abstract}

Keywords: Calotropis procera, Solvent extraction, phytochemical analysis, antimicrobial activity.

\section{INTRODUCTION:}

Herbs and plants have been in use as a source of therapeutic compounds in a traditional medicinal system since ancient time. There is a continuous need for the development of new effective antimicrobial drugs because of the emergence of new infectious diseases and drug resistance [1,2]. Calotropis procera R. Br. (Asclepiadaceae) has been known to the traditional systems of medicine and plant known asMadar in an Unani system of medicine. The generic name Calotropis is taken from Kalos( beautiful) and Tropis ( a kneel), alluding good look of the kneel of the flower.Calotropis procera is regarded as the useful medicinal plant which is used in folk medicine and also popularly known because it produces a large quantity of latex(milk).There are two common species of Calotropis, viz. Calotropis gigantea (Linn.) R.Br. and Calotropis procera (Ait.) R. $\mathrm{Br}$ described by the Sanskrit writers [3]. In spite of different appearances, both of the plant species share the common chemical constituents. It has been widely used in the Sudanese, Unani, Arabic and Indian traditional medicinal system for the treatment of various diseases namely leprosy, ulcers, piles and diseases of the spleen, liver and abdomen [4]. Latex present in the plant containsabortifacient, spasmogenic and carminative, antidysenteric, antisyphilitic, antirheumatic, antifungal properties. Besides, it can be used for the treatment of bronchial asthma and skin affliction. The current study was aimed to carry out the phytochemical screening and to check invitro antibacterial activity against E. coli using the respective extracts prepared. 
Table 1: Classification of Calotropis procera:

\begin{tabular}{|l|l|}
\hline Kingdom & Plantae \\
\hline Division & Magnoliophyta \\
\hline Class & Magnoliopsida \\
\hline Subclass & Asteridae \\
\hline Order & Gentianales \\
\hline Family & Asclipiadaceae \\
\hline Subfamily & Caesalpinioideae \\
\hline Genus & Calotropis \\
\hline Species & procera \\
\hline
\end{tabular}

\section{MATERIALS AND METHODS:}

\section{Plant Material Collection and Authentication:}

Leaves and roots of Calotropis procera used in this study were collected from the campus of IILMAcademy of Higher Learning, Greater Noida, U.P, India in the month of August 2017 and were positively identified by Associate Professor, Dr. Avijit Guha which was further cleaned with distilled water and left to get dry at room temperature in the laboratory of Department of Biotechnology, IILM Academy. Morphological Studies were carried out by using simple determination technique, the shape, size, color, odor, margin and apex.

\section{Preparation of extracts:}

Dried leaves were uniformly grinded using the mechanical grinder.

Distilled water extract (aqueous extraction): The leaves powder was extracted in distilled water.5gm of plant powder was soaked in $50 \mathrm{ml}$ of distilled water in a conical flask and loaded on an orbital shaker at a speed $120 \mathrm{rpm}$ for $24 \mathrm{hrs}$. The mixture was filtered using the muslin cloth.An extract was concentrated in rotavapor and dried by using lyophilizer.

Methanol extract): $5 \mathrm{gm}$ of each powdered leaf sample in 2 different small conical flasks is taken and extracted with a mixture of methanol: water $(7: 3, \mathrm{v} / \mathrm{v})$ by a Soxhlet apparatus for 72 hours. The solvent was completely removed and obtained dried crude extract which was used for investigation.

Acetone extract: A $25 \mathrm{gm}$ of powdered leaves was added to $70 \%$ acetone at $55^{\circ} \mathrm{C}$ for $48 \mathrm{~h}$. The obtained extract was further filtered with Whatman No 1 filter paper and then allowed to evaporation. After evaporation, the sample was in the form of powder (concentrated form) and this form was stored at $4^{\circ} \mathrm{C}$ untilfurther use.

\section{Sterilization of Materials:}

The Petri dishes and pipettes packed into metal canisters were appropriately sterilized in the hot air oven at $170^{\circ} \mathrm{C}$ for $1 \mathrm{~h}$ at each occasion. The solution of the extract and culture media were autoclaved at $121^{\circ} \mathrm{C}$ for $15 \mathrm{~min}$.

\section{Maintenance of Test Organisms}

The microorganisms were maintained by weekly subculturing on agar slant. Before each experiment, the organism was activated by successive sub-culturing and incubation.

\section{PHYTOCHEMICAL ANALYSIS:}

Quantitative assay for the presence of phytochemical constituents was performed using Standardized methods for the phytochemical analysis of the plant extracts.

\section{Test of alkaloids}

One milliliter of aqueous extract was stirred and placed in $1 \%$ aqueous hydrochloric acid on a steam bath, Then, $1 \mathrm{~mL}$ of the filtrate was treated with Dragedorff's reagent. Turbidity or precipitation with this reagent was considered as evidence for the presence of alkaloids [5].

\section{Test of carbohydrates}

Benedict's test-Test solution was mixed with few drops of Benedict's reagent (alkaline solution containing cupric citrate complex) and boiled in the water bath, observed for the formation of reddish-brown precipitate to show a positive result for the presence of carbohydrate [5].

\section{Test of phenols}

Extracts were treated with 3-4 drops of ferric chloride solution. Formation of bluish black colour indicates the presence of phenols [5]. 


\section{Test of saponins}

About $2 \mathrm{~g}$ of the powdered sample was boiled in $20 \mathrm{ml}$ of distilled water in a water bath and filtered. $10 \mathrm{ml}$ of the filtrate was mixed with $5 \mathrm{ml}$ of distilled water and shaken vigorously for a stable persistent froth. The frothing was mixed with 3 drops of olive oil and shaken vigorously, then observed for the formation of emulsion [6].

1 .

\section{Test of flavonoids}

A portion of the powdered plant sample was in each case heated with $10 \mathrm{ml}$ of ethyl acetate over a steam bath for $3 \mathrm{~min}$. The mixture was filtered and $4 \mathrm{ml}$ of the filtrate was shaken with $1 \mathrm{ml}$ of dilute ammonia solution. A yellow coloration was observed indicating a positive test for flavonoids becomes colorless on the addition of dilute acid, indicates the presence of flavonoids [6].

\section{Test of proteins}

To the extract ninhydrin reagent (2,2 -dihydroxyindene1,3-dione) was added and boiled for few minutes. Formation of the blue colour indicates the presence of amino acid.

\section{Test of tannins}

About $0.5 \mathrm{~g}$ of the extract was boiled in $10 \mathrm{ml}$ of water in a test tube and then filtered. A few drops of $0.1 \%$ ferric chloride was added and observed for brownish green or a blue-black colouration [7].

\section{Test of terpenoids}

$5 \mathrm{ml}$ of each extract were mixed in $2 \mathrm{ml}$ of Chloroform and $3 \mathrm{ml}$ Concentrated sulphuric acid was carefully added to form a layer. A reddish brown colour at the interface indicates the presence of terpenoids [8].

\section{DETERMINATION OF ANTIMICROBIAL ACTIVITY:}

\section{Test microorganisms and control:}

The aqueous extract of the leaves of $C$. procerawas tested against pathogenic bacteria E. coli. The sample of E. coli was obtained from the clinical sample. The isolated culture in nutrient agar medium was subcultured in a nutrient broth which was kept at $37^{0} \mathrm{C}$ for 24 hours.Polymyxin-B was used as the control for E. colicells.

\section{Antimicrobial assay:}

Agar well diffusion method was used to determine the antimicrobial activity. E. coli suspension was seeded on two MHA plates in a sterilized condition. In each of these plates, two wells were punched using a sterilized corn borer. Using a micropipette $50 \mu \mathrm{l}$ of methanol extract and control was loaded in the first plate and again, the same concentration of acetonic and aqueous extract was added in the second plate. Plates were incubated for 24 hours at $37^{\circ} \mathrm{C}$.

This method of the antibacterial activity assessment was based on the diameter measurement of the inhibition zone formed around well. The effects were compared with that of the standard antibiotic Polymyxin-B

\section{RESULT\& DISCUSSION:}

\section{Phytochemical screening:}

Phytochemical test of three different extracts is shown in Table 2. All the three extracts showed the presence of carbohydrates and saponins. Alkaloids, proteins and tannins presence was seen in methanol and acetone extract. Further Flavonoids presence was seen in the methanol and aqueous extract.

\section{Antimicrobial activity:}

Various zone of inhibition was observed with different extracts. We came to know that different form of extracts has different antimicrobial potential. The controlled region showed inhibition zone of $13.5 \mathrm{~mm}$, the aqueous, acetonic and methanolic extract showed inhibition zone of $6 \mathrm{~mm}, 4 \mathrm{~mm}$ and $9.5 \mathrm{~mm}$ (Table 3). Maximum zone of inhibition was shown with the methanolic extract.

\section{Conclusion:}

In this study, the medicinally important $C$. procera was selected for the phytochemical screening of methanol, acetone and aqueous extract and assessed its antimicrobial activity against E. coli. The World Health Organization (WHO) reported that about $80 \%$ of the world's population depends mainly on traditional medicine and the traditional treatment involve mainly the use of plant extracts [9].Our basic aim was to study the pharmaceutically important plant where $C$. procera was taken as a choice. It was found that methanol extract showed the higher zone of inhibition with higher potential to be an antimicrobial. Maximum 
antimicrobial activity was observed due to the presence of high amounts of secondary metabolites. Based on our results, we concluded that methanol extract of $C$. procera ha the great potential activity as an antimicrobial agent which can be used as medicine in the treatment of infectious diseases caused by antibiotics resistant microorganism.

\section{Acknowledgement}

The authors are grateful to the Head, Department of Biotechnology, IILM College of Engineering and Technology, Greater Noida to provide necessary laboratory facilities to pursue this research work.

\section{REFERENCES:}

1. Richard EL, "Bacterial evolution and the cost of antibiotic resistance". InternatlMicrobiol 1998;1(4):265-270.

2. Raghunath D, "Emerging antibiotic resistance in bacteria with special reference to India". J Biosci 2008;33(4):593-603.

3. Yelne MB, Sharma PC, Dennis TJ. "Database on medicinal plants used in Ayurveda", central council for research in Ayurveda and Siddha, New Delhi; Vol. 2,69-73(2000)

4. Kartikar KR, Basu BD. "Indian Medicinal Plants", Lalit Mohan Basu, Leader road, Allahabad; 2nd ed,
1606-1609, (1994).

5. Prakash, V., Saxena, S., Gupta, S., Saxena, A.K., Yadav, R. and Singh, S.K., "Preliminary Phytochemical screening and Biological Activities of Adina cardifolia.", Journal of Microbial \& Biochemical Technology, 2015.

6. Edeoga, H.O., Okwu, D.E. and Mbaebie, B.O., "Phytochemical constituents of some Nigerian medicinal plants." African journal of biotechnology, 2005, 4(7), pp.685-688.

7. Ayoola, G.A., Coker, H.A.B., Adesegun, S.A., Adepoju-Bello, A.A., Obaweya, K., Ezennia, E.C. and Atangbayila, T.O.,"Phytochemical screening and antioxidant activities of some selected medicinal plants used for malaria therapy in Southwestern Nigeria". Trop J Pharm Res, 2008, 7(3), pp.1019-1024.

8. Singh, M.P. and Saxena, S., "Phytochemical analysis and antimicrobial the efficacy of methanolic extract of some medicinal plants at Gwalior region." Journal of Pharmacy Research, 2011, 4 .

9. WHO, "Summar 9 WHO guidelines for the assessment of herbal medicines." Herbal Grom, 1993, 28, 13-14.

Table 2: Preliminary phytoconstituents screening of different extracts of Calotropis procera

\begin{tabular}{|l|l|l|l|}
\hline Phytochemicals & $\begin{array}{l}\text { Methanol } \\
\text { extract }\end{array}$ & $\begin{array}{l}\text { Acetone } \\
\text { extract }\end{array}$ & $\begin{array}{l}\text { Aqueous } \\
\text { extract }\end{array}$ \\
\hline Alkaloids & $+\mathrm{ve}$ & $+\mathrm{ve}$ & -ve \\
\hline Carbohydrates & $+\mathrm{ve}$ & $+\mathrm{ve}$ & $+\mathrm{ve}$ \\
\hline Phenols & $-\mathrm{ve}$ & $-\mathrm{ve}$ & $-\mathrm{ve}$ \\
\hline Proteins & $+\mathrm{ve}$ & $+\mathrm{ve}$ & $-\mathrm{ve}$ \\
\hline Saponins & $+\mathrm{ve}$ & $+\mathrm{ve}$ & $+\mathrm{ve}$ \\
\hline Flavonoids & $+\mathrm{ve}$ & $-\mathrm{ve}$ & $+\mathrm{ve}$ \\
\hline Tannins & $+\mathrm{ve}$ & $+\mathrm{ve}$ & $-\mathrm{ve}$ \\
\hline Terpenoids & $-\mathrm{ve}$ & $-\mathrm{ve}$ & $-\mathrm{ve}$ \\
\hline Anthocyanin & $-\mathrm{ve}$ & $-\mathrm{ve}$ & $-\mathrm{ve}$ \\
\hline
\end{tabular}

Where +ve shows presence and -ve shows the absence of phytoconstituents. 
Table3: Antimicrobial activity of leaves extract of Calotropis procera on E. coli

\begin{tabular}{|c|c|}
\hline Solvent Extract & Zone of Inhibition(mm) \\
\hline Methanolic extract & 9.5 \\
\hline Acetone extract & 4 \\
\hline Aqueous extract & 6 \\
\hline Control (Polymyxin-B) & 13.5 \\
\hline
\end{tabular}

